\title{
Dawno, dawno temu na przedmieściach. Baśniowość w filmie Edward Nożycoręki Tima Burtona
}

Tim Burton zasłynął jako etatowy „dziwak” Hollywoodu. Jest reżyserem tworzącym filmy nieco mroczne i nieco makabryczne, a zarazem pełne humoru i melancholii. Są nietypowe i wyróżniają się na tle mainstreamowego kina amerykańskiego. Nie przeszkodziło im to jednak w zdobyciu ogromnej popularności, dzięki której z głosem reżysera identyfikują się ludzie na całym świecie. Trzeba jednak podkreślić, że Burton, choć wychowany na idyllicznych amerykańskich przedmieściach, całe życie czuł się społecznym wyrzutkiem. Badając jego twórczość, łatwo zauważyć powracające motywy i charakterystyczny styl, które tworzą poetykę jego filmów i sprawiają, że przemawiają one do tak wielu odbiorców. Jednym z bardzo wyrazistych i często powracających elementów jego artystycznego języka jest baśniowość, szczególnie ciekawie wykorzystywana w filmie Edward Nożycoręki. Odwołując się do teorii baśni Władimira Proppa, będę starała się pokazać funkcje, jakie w tym obrazie pełnią elementy baśniowe[1].

Na pierwszy rzut oka historia Edwarda Nożycorękiego może się zdawać prostą, choć mroczną opowiastką - niczym więcej niż ponownie opowiedzianą historią potwora Frankensteina. Przy głębszej analizie zyskuje jednak nowy wymiar. Na początek warto przypomnieć sobie jej przebieg. Poznajemy Edwarda, „potwora” stworzonego przez szalonego naukowca mieszkającego w gotyckim zamku. Naukowiec jednak umiera, zanim zdąży ukończyć swoje dzieło, dlatego Edward zostaje skazany na życie z nożycami zamiast rąk. Mieszka w izolacji, zajmuje się ogrodem i obserwuje przez okna swego zamku idylliczne przedmieścia znajdujące się u stóp góry, na której mieszka. Pewnego dnia zjawia się u niego sprzedawczyni kosmetyków. Poruszona jego samotnością, zabiera go ze sobą na dól, aby zamieszkał z jej rodziną w jednym z domków na przedmieściach. Tu Edward zaczyna przystosowywać się do życia w małomiasteczkowej społeczności. Znajduje przyjaciół i wrogów, a także zakochuje się w Kim, córce swojej wybawicielki. Kim ma jednak chłopaka, Jima, który staje się głównym przeciwnikiem Edwarda na drodze do zdobycia jej miłości. Z czasem mieszkańcy przedmieść przestają tolerować inność Edwarda. Ich sympatie obracają się przeciwko niemu, co prowadzi do wypędzenia Edwarda z powrotem na jego górę i przyczynia się do finałowej konfrontacji.

[1] W całości pracy będę zamiennie stosować określenia „baśń” oraz „bajka magiczna”. Hasło „bajka magiczna” w: Słownik folkloru polskiego, red. J. Krzyżanowski, Warszawa 1965, s. 34. 
Mimo usytuowania historii Edwarda we współczesnym świecie, w miejscu tak banalnym i niewyróżniającym się jak amerykańskie przedmieścia, kontekst baśniowy zostaje narzucony już na początku filmu. W pierwszej i ostatniej scenie Edwarda Nożycorękiego Burton tworzy ramę narracyjną, która otwiera i zamyka film niczym wrota prowadzące do magicznej krainy. W pierwszej scenie widzimy babcię, która pewnego śnieżnego wieczoru opowiada wnuczce bajkę na dobranoc - Burton zdaje się mrugać porozumiewawczo do odbiorcy, kreując odwołującą się do stereotypów na temat transmisji folkloru figurę staruszki[2], i po chwili daje mu jeszcze bardziej dosłowne odniesienie do tego gatunku. Babcia rozpoczyna swoją opowieść słowami: „Dawno temu był sobie nawet mężczyzna, który miał noże zamiast rąk...”[3], odwołując się do baśniowej formuliczności[4]. W jej opowieści świat amerykańskich przedmieść zamienia się w baśniową krainę: stara rezydencja na szczycie góry staje się mrocznym zamkiem, człowiek-robot zostaje upodobniony do baśniowego potwora o dobrym sercu, a piękna cheerleaderka, w której zakochuje się bohater, w oczach widza jest już księżniczką. Takie elementy, jak zamek, potwór czy księżniczka to jedynie najbardziej widoczne nawiązania do bajki magicznej. Przy głębszej analizie można zauważyć, że nawet te elementy, które zdają się należeć do świata realistycznego, odzwierciedlają często świat magiczny. Poświęcę temu więcej uwagi w dalszej części pracy.

Rysujący się przed oczami widza obraz wydaje się jednak dosyć mocno zakorzeniony w realnym świecie. $Z$ tego powodu można przeoczyć dużo ważniejsze przesłanki wskazujące na przynależność filmu Edward Nożycoręki do gatunku baśni. Najważniejszą z nich jest sama struktura filmu, która zdaje się w znacznym stopniu odzwierciedlać konstrukcję baśni opisaną przez Władimira Proppa. Propp w swojej przełomowej publikacji Morfologia bajki wskazuje na stałą strukturę występującą we wszystkich bajkach magicznych, na którą składa się trzydzieści jeden funkcji[5]. Badacz zwraca także uwagę na obecność siedmiu typów postaci, które stają się nośnikami tych funkcji[6]. Zbudowana $\mathrm{z}$ tych elementów struktura pozwala na tworzenie skończonej ilości wariantów fabularnych[7]. W związku z tym Propp zauważa, że „[...] fabuły - w szczególności fabuły bajek magicznych - są ściśle ze

[2] Utrwalony w kulturze popularnej obraz staruszki opowiadającej bajki może być zakorzeniony w tradycji snucia opowieści przez babcie i niańki, czyli w tzw. bajce żeńskiej. W. Propp, Nie tylko bajka, przeł.

D. Ulicka, Warszawa 2000, s. 82.

[3] Edward Nożycoręki, reż. Tim Burton [DVD], 2oth Century Fox, 1990, USA. Wszystkie tłumaczenia z języka angielskiego w przekładzie własnym.

[4] J. Ługowska, Ludowa bajka magiczna jako tworzywo literatury, Wrocław 1981, s. 86-93.

[5] „Przez funkcję rozumiemy postępowanie osoby działającej, określane z punktu widzenia jego zna- czenia dla toku akcji”. W. Propp, Morfologia bajki, przeł. W. Wojtyga-Zagórska, wstęp B. Gołębiowski, Warszawa 1976, s. 59.

[6] B. Gołębiowski, Morfologia bajki a morfologia autobiografii kultur, narodów i ludzi, w: W. Propp, Morfologia bajki, op. cit., s. 16.

[7] W innym swoim dziele Propp twierdzi także, że „bogactwo bajki nie zawiera się w kompozycji, lecz $\mathrm{w}$ tym, w jak różnorodny sposób realizuje się jeden i ten sam element kompozycyjny". W. Propp, Historyczne korzenie bajki magicznej, przeł. J. Chmielewski, Warszawa 2003, s. 49. 
sobą związane. Stwierdzenie, gdzie kończy się jedna fabuła wraz z jej wariantami, a gdzie zaczyna się inna, możliwe jest jedynie po przeprowadzeniu międzyfabularnych badań nad bajką [...]"[8]. Przy dogłębnej analizie Edwarda Nożycorękiego można dostrzec opisane przez Proppa elementy strukturalne oraz uznać ten film za nowy, uwspółcześniony wariant baśni.

W filmie Burtona można wyodrębnić aż sześć z siedmiu typów postaci i co najmniej dwadzieścia pełnionych przez nie funkcji[9]. W Edwardzie można rozpoznać bohatera, w Jimie - jego przeciwnika, Kim to królewna, Peg oraz Joyce - pomocnicy i darczyńcy, a osobą wysyłającą jest twórca Edwarda. Postaci te pełnią swoje funkcje zgodnie z zasadą: „Następstwo funkcji jest zawsze jednakowe”[10]. Akcję rozpoczyna 'odejście'[11], reprezentowane przez śmierć wynalazcy i opuszczenie przez Edwarda domu. Później pojawia się 'rozkaz', czyli propozycja Peg, aby Edward wrócił z nią do jej domu. Następnie 'wykonanie rozkazu', 'wywiadywanie się przeciwnika' i tak dalej: bohater wyrusza na 'wyprawę, mają miejsce 'podstępy' i 'trudne zadania', pojawiają się pomocnicy i darczyńcy, którzy popychają akcję filmu do przodu i pomagają bohaterowi dotrzeć do końca swojej przygody. Nie braknie finałowej 'walki z przeciwnikiem' (antagonistą) Edwarda, a także 'wesela' pod postacią wyznania miłosnego ze strony Kim.

Poszukując baśniowości w filmie Edward Nożycoręki, nie sposób jednak ograniczyć się do analizy jego struktury - konieczne jest także uwzględnienie jego stylistyki oraz cech narracji bajki magicznej. Najwięcej na ten temat pisał szwajcarski literaturoznawca Max Lüthi[12]. Jedną z cech narracji, które opisuje Lüthi, jest „doniosłe zjawisko powtarzania i zmiany"[13]. Teoretyk odnosi się tu zarówno do powtórzeń fabularnych w różnych bajkach, jak również do powtórzeń występujących wewnątrz każdej bajki. „Nie trzeba opowiadać niczego innego niż to, co opowiedziano za pierwszym razem. A jednak nie opowie się tego dokładnie tak samo. Z powtórzeniem łączy się z przekształcenie"[14], twierdzi Lüthi. Tak jak bajkowy rycerz musi stawić czoła trzem smokom $\mathrm{w}$ trzech pojedynkach, a każdy $\mathrm{z}$ nich jest trochę inny od poprzedniego, tak zadania Edwarda powtarzają się zgodnie z tą zasadą. Trzy razy Edward zajmuje się strzyżeniem, aby zaskarbić sobie sympatię społeczności, i za każdym razem następuje drobna zmiana. Najpierw strzyże żywopłoty, potem psią sierść, a na koniec ludzkie włosy. Jego zadania mimo swojej powtarzalności stają się coraz trudniejsze[15].

[8] Ibidem, s. 41-42.

[9] Zgodnie z teorią Proppa „trzeba stwierdzić, że bynajmniej nie we wszystkich bajkach występują wszelkie możliwe funkcje”. W. Propp, Morfologia bajki, op. cit., s. 61.

[10] Ibidem, s. 14.

[11] Określenia ujęte w cudzysłów pojedynczy (definicyjny) stanowią zbiór pojęć używanych przez Proppa na określenie funkcji. Ibidem, s. 239-246.
[12] „Lüthi stwierdza, że analiza struktury bajki dokonana przez Proppa i jego własna analiza stylu uzupełniają się wzajemnie”. A. Mojkowska, Max Lüthi jako bajkoznawca, Wrocław 2006, s. 18.

[13] M. Lüthi, Cechy narracji w bajce ludowej, „Literatura ludowa" 1982 , nr 2, s. 64.

[14] Ibidem, s. 64.

[15] O potrojeniu pisał także W. Propp. Idem, Morfologia bajki, op. cit., s. 136-138. 
Edward, nieoswojony z życiem w społeczeństwie, z każdym nowym strzyżeniem przybliża się do ludzi: najpierw zostaje wpuszczony do ich ogrodów, później może zbliżyć się do ich ukochanych zwierząt, a na koniec staje twarzą w twarz z mieszkankami przedmieść. Gdy dopuszczają one Edwarda do swoich włosów, pierwotnego symbolu siły i seksualności, pomagają mu przejść inicjację, której rezultatem jest integracja ze społeczeństwem. Zgodnie z twierdzeniem Lüthiego „tam, gdzie mowa jest o stopniowaniu, zwrot przynosi zazwyczaj dopiero trzeci element triady, np. dopiero trzecia walka jest zwycięska”[16]. Każde kolejne powtórzenie wiąże się $\mathrm{z}$ narastaniem i to trzecia próba (lub wydarzenie) jest najważniejsza i najtrudniejsza. Innym tego przykładem jest zmiana surowców, z jakich Edward tworzy swoje rzeźby. Najpierw jest to roślina (żywopłot), później włos (zwierzęcy i ludzki) i dopiero na końcu, gdy zwycięsko dociera do końca swojej inicjacji, rzeźbi dzieła w lodzie. Powtórzenie i zmiana są także obecne w trzech scenach, gdy nożyce Edwarda tną ciało drugiego człowieka. Najpierw jest to lekkie draśnięcie dłoni Kim, całkowicie przypadkowe i płytkie. Później znacznie bardziej rani jej brata, choć ratuje go spod kół samochodu. Na koniec zadaje cios już całkowicie świadomy i śmiertelny, gdy w finałowej walce zabija swojego przeciwnika ciosem w brzuch. Można zauważyć, że zjawisko powtórzenia ze zmianą, a także potrajania wydarzeń, występuje w całym filmie.

Wyrazista konstrukcja bajki opiera się nie tylko na potrojeniach, ale także na polaryzacji świata przedstawionego. Kontrastujące zestawienie dwóch cech, postaci lub wydarzeń sprawia, że świat przedstawiony jest wyrazisty i czytelny, a występujące w nim ekstremy - podkreślone. Lüthi tak opisuje to zjawisko: „Bajka czyni swymi bohaterami osoby z najodleglejszych krańców społeczeństwa [...]. Lubi ona zresztą w ogóle ekstremy i kontrasty: straszliwe kary i wspaniałe nagrody, [...] dobre i złe, piękne i odrażające, czarne i białe. I tak rysuje świat przejrzysty, o czystej konstrukcji”[17]. Postaci bohatera i królewny w filmie Edward Nożycoręki są ukazane zgodnie z tą zasadą i stanowią najlepszy jej przykład. Z jednej strony równania mamy Edwarda, „potwora”, wyrzutka i dziwaka. Jest mroczny, wygląda nieco przerażająco, stanowi pewne kuriozum. Po drugiej stronie widzimy Kim, odzwierciedlającą wszystko, co społeczeństwo wielbi: młodość, piękno, radość. Zestawienie tych dwojga ukazuje silny, znaczący kontrast. W filmie można zaobserwować także inne dychotomie. Skontrastowane zostaje konformistyczne społeczeństwo i nonkonformistyczny indywidualista. Dobro i niewinność ze złym, gotowym na wyzyskiwanie jednostek światem. Czerń i biel Edwarda z pastelowymi, nijakimi kolorami przedmieść. Kraina „u góry” i jej magiczny zamek przeciwstawiany jest krainie „na dole” i jej zwykłym domkom. Na równych, typowych, przystrzyżonych trawnikach stają bajeczne rzeźby z żywopłotów, a największe serce ma

[16] A. Mojkowska, Max Lüthi jako bajkoznawca, op. cit., s. 44.
[17] M. Lüthi, Zabójca smoka. O stylu bajki, „Literatura Ludowa" 1982, nr 3, s. 38. 
maszyna, która de facto serca nie posiada. Film Burtona maksymalnie wykorzystuje polaryzację charakterystyczną dla baśniowego świata.

Kolejną cechą baśni jest powracająca abstrakcyjność i cudowność: „Jeżeli idzie o aspekt stylistyczny, to widać, jak dychotomia i trójczłonowość wręcz determinuje użycie w bajce stylu abstrakcyjnego" [18], zauważa Agnieszka Mojkowska. W świecie bajki to, co abstrakcyjne czy też cudowne, nie musi być racjonalizowane[19]. Bohaterowie bajki napotykają na swojej drodze postaci ze świata magicznego, nadnaturalnego, ale zetknięcie się z nimi przeżywają „bez żadnego wewnętrznego poruszenia” [20]. Ta zasada „braku zdziwienia” [21] jest odzwierciedlona w filmie Burtona w reakcji mieszkańców miasteczka na pojawienie się Edwarda. Nikogo nie dziwi, że „potwory istnieją?. Reakcja na ożywiony przez szalonego naukowca twór (który na dodatek posiada noże zamiast rąk) jest reakcją porównywalną do spotkania ze zwykłym ekscentrykiem, który ubiera i zachowuje się trochę inaczej niż przyjęto. Odzew społeczności można opisać jako lekką ekscytację i zaciekawienie, ale na pewno nikt nie zadaje pytania: „Jak to jest możliwe?”. Cudowność świata filmu na tym

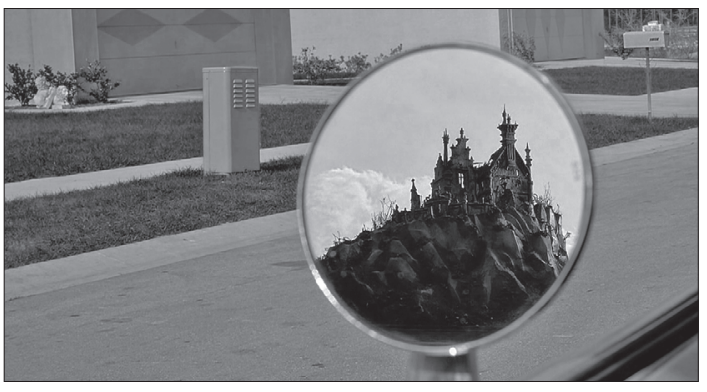
jednak się nie kończy. Skąd bierze się lód, z którego rzeźbi Edward, i czemu nigdy się nie topi? Jak mieszkańcy miasteczka mogli nie zainteresować się zamczyskiem na górze? W jaki sposób „żywi się” Edward i czemu nie wyczerpują mu się „baterie”? „[W baśniach - przyp. A.F.] jest pewna ilość symbolizmu, pewna ilość interpretacji i abstrakcji, którą doceniam" [22], twierdzi Burton, a Edward Nożycoręki stanowi dowód na poparcie jego słów, przypominając swoim stylem baśń.

O ile stosunkowo łatwo jest najogólniej rozpoznać w filmie Burtona gatunek baśniowy, o tyle można przeoczyć fakt, że jest to baśń wykorzystująca wątki inicjacyjne. Ten typ baśni obrazuje za pomocą struktur i narzędzi bajki magicznej rytuał wtajemniczenia. Bohater takiej baśni musi odejść z domu i wyruszyć w podróż, która ma go doprowadzić ze świata niewinności do świata doświadczenia[23]. Propp

Edward Nożycoręki, reż. Tim Burton (USA, 1990).

Nikogo z mieszkańców przedmieść nie dziwi obecność zamczyska na szczycie góry. Bliska koegzystencja świata nadprzyrodzonego $\mathrm{z}$ realistycznym jest typowa dla bajek magicznych.
[18] A. Mojkowska, Max Lüthi jako bajkoznawca, op. cit., s. 46.

[19] Roger Caillois także porusza ten temat. W swoim eseju Od baśni do science-fiction podkreśla, że: „Baśniowość to świat cudowności, który łączy się ze światem rzeczywistym, nie naruszając w niczym jego wewnętrznego ładu i nie niszcząc jego spójności [...]. Baśń dzieje się w świecie, w którym czary są naturalne, a magia regułą. Pierwiastek nadprzyrodzony nie jest w nim straszny, nawet nie dziwny, bo stanowi on substancję tego świata, [...] należy do porządku rzeczy”. R. Caillois, Od baśni do science-fiction, przeł. J. Lisowski, w: idem, Odpowiedzialność i styl. Eseje, Warszawa 1967, s. 32-33.
[20] A. Mojkowska, Max Lüthi jako bajkoznawca, op. cit., s. 47 .

[21] Ibidem, s. 49.

[22] T. Burton. Burton on Burton, red. M. Salisbury, London 2006, s. 94.

[23] Mircea Eliade, wybitny religioznawca, tak opisuje znaczenie obrzędu inicjacyjnego: „Obrzędy przejścia - tam gdzie istnieją - są obowiązkowe dla wszystkich młodych członków plemienia. Aby mieć prawo zostania dopuszczonym między dorosłych, młodzieniec musi stawić czoła wielu próbom inicjacyjnym: dzięki tym obrzędom i zawartym w nich objawieniom będzie uznany za odpowiedzialnego członka społeczeństwa. Inicjacja wprowadza nowicju- 
w swojej pracy Historyczne korzenie bajki magicznej podkreśla, że: „[...] cykl związany z inicjacją stanowi najstarszą podstawę bajki”[24]. Analizując historię Edwarda, można zauważyć elementy „obrzędu wtajemniczenia młodzieży osiągającej dojrzałość” [25], a proces inicjacyjny wydaje się mieć kluczowe znaczenie dla przebiegu filmu.

Pierwsze oznaki rytuału inicjacyjnego obserwujemy już na samym początku filmu, kiedy Peg pojawia się w zamczysku Edwarda i zabiera go do miasteczka. Propp opisuje początek typowej inicjacji jako „prowadzenie dzieci przez rodziców [...] do lasu”[26], a w filmie Burtona możemy zauważyć odzwierciedlenie tego etapu, choć schemat zostaje nieco przełamany. Na początek warto zwrócić uwagę na to, że Peg nie jest matką Edwarda, mimo że to właśnie rodzic powinien poprowadzić dziecko ku inicjacji. Tę drobną różnicę można tłumaczyć tym, że w momencie kiedy poznajemy Edwarda, jest on już sierotą i potrzebna była inna postać, aby spełnić funkcję rodzica. Peg od pierwszych scen filmu kreowana jest na bardzo ciepłą i opiekuńczą osobę, która przygarniając Edwarda do swojego domu i zajmując się jego wychowaniem, de facto staje się jego matką. Drugą różnicą między opisaną przez Proppa a filmową inicjacją jest brak lasu. Badacz twierdzi: „Obrzęd wtajemniczenia odbywał się zawsze w lesie. To jego stała, niezmienna cecha na całym świecie” [27], a sam las można uznać za strefę graniczną, przez którą prowadzi droga do „innego świata" [28]. Usytuowanie historii Edwarda w małomiejskiej społeczności wpłynęło na przekształcenie tego elementu rytuału inicjacyjnego. Zdaje się, że Burton postawił na odwrotny kierunek podróży młodzieńca. O ile normalnie opuszcza on społeczeństwo (reprezentowane przez wioskę, miasteczko czy jednostkę rodzinną), aby wejść do lasu w samotności, o tyle Edward rozpoczyna swoją podróż jako samotnik mieszkający poza wspólnotą, którego inicjacja prowadzi ku społeczeństwu. Ciekawą analogią wydaje się to, że o ile las uznawany był za strefę przejściową na drodze do „innego świata”, tak przedmieścia mogą pełnić podobną funkcję w wędrówce do miasta (pełniącego centralną rolę w życiu społecznym). Motyw lasu nie został jednak całkowicie pominięty i zgodnie z twierdzeniem Proppa, że „tam gdzie nie ma lasu, dzieci prowadzi się chociażby w zarośla" [29], Edward od początku filmu otacza się krzakami i żywopłotami, które odgrywają ważną rolę w jego inicjacji[30].

Za fizyczne przejście oznaczające początek obrzędu Edwarda można uważać bramę[31], która oddziela jego posesję od przedmieść.

sza zarazem do wspólnoty ludzkiej i w świat wartości duchowych". M. Eliade, Inicjacja, obrzędy, stowarzyszenia tajemne. Narodziny mistyczne, przeł. K. Kocjan, Kraków 1997, s. 8.

[24] W. Propp, Historyczne korzenie bajki magicznej, op. cit., s. 396.

[25] Ibidem, s. 51.

[26] Ibidem, s. 83 .

[27] Ibidem, s. 54 .

[28] Ibidem, s. 55 .
[29] Ibidem, s. 54.

[30] Tworzenie rzeźb z krzaków i żywopłotów staje się jednym z pierwszych zadań, jakich podejmuje się Edward na drodze do zostania częścią społeczności. [31] Znaczenie fizycznych przejść (takich jak drzwi, progi i bramy) w rytach inicjacyjnych opisał francuski etnolog i folklorysta Arnold Van Gennep w pracy Obrzędy przejścia. Systematyczne studium ceremonii, Warszawa 2006, s. 40-50. 
Jest ona ukazana dosyć szczegółowo w scenie przybycia Peg do zamku. Peg zatrzymuje się na krótką chwilę, przyglądając się bramie, zanim przejdzie przez nią i wejdzie do zamku. Podkreśla to powagę sytuacji, jaką jest przejście granicy między dwoma światami. Dodatkowo brama jest przyozdobiona wizerunkami najróżniejszych zwierząt. Propp podkreśla znaczenie symboliki zwierząt, w które młodzieniec poddawany inicjacji miałby się wcielić[32] bądź zostać przez nie symbolicznie pożartym[33]. W przypadku bramy przyozdobionej wizerunkami zwierząt na myśl przychodzi nawiązanie do „zwierząt, strzegących wejścia do piekieł"[34]. Cała wędrówka, od progu zamku, w dół do bramy i niżej do miasteczka, wiąże się z kolejną cechą rytualną, a mianowicie z „drogą w dół”. Kraina, do której bohater udaje się w swojej wędrówce, często znajduje się „pod ziemią”[35], a podróż do niej i schodzenie w dół wiąże się z wyobrażeniem o tymczasowej śmierci w trakcie rytuału inicjacyjnego[36].

Gdy bohater dostaje się już „pod ziemię” i rozpoczyna właściwą część inicjacji, jako jeden z pierwszych elementów pojawia się motyw pojenia i karmienia[37]. Propp zauważa, że „spożywając pokarm przeznaczony dla umarłych, przybyły wstępuje ostatecznie do ich świata"[38]. Motyw posilania się powraca w filmie kilkukrotnie. Po pojawieniu się Edwarda w domu Peg odbywa się pierwszy wspólny posiłek, który pozwala zobaczyć, z jaką trudnością przychodzi Edwardowi konsumowanie pokarmu. $Z$ powodu braku dłoni nie jest w stanie korzystać ze sztućców, a nożyce, które ma zamiast rąk, nie pomagają mu w dostarczeniu jedzenia do ust. Z czasem, gdy przebywa w społeczności dłużej, nabiera w tym wprawy. W innej scenie Edward jest karmiony na siłę przez Joyce, której słynna sałatka nosi znaczącą nazwę - ambrozja[39]. To bezpośrednie odwołanie do pokarmu bogów ponownie przypomina nam o ukrytym znaczeniu spożywania posiłków w tym filmie. Z kolei motyw pojenia pojawia się zaraz po scenie, w której Edward poznaje Kim. Pierwsze zetknięcie z nią i zakochanie się stają się momentem, w którym młodzieniec zaczyna tracić swoją niewinność Kiedy Kim reaguje krzykiem na widok Edwarda, jej ojciec częstuje młodzieńca alkoholem dla uspokojenia nerwów. Odurzające działanie napoju oraz fakt, że został podany niedoświadczonemu chłopakowi przez doświadczonego mężczyznę, świadczą o tym, że jest to ważna część rytuału.

Kolejnym elementem nawiązującym do obrzędów inicjacyjnych jest skaryfikacja. Bohater wielokrotnie tnie się po twarzy, a czasem

[32] W. Propp, Historyczne korzenie bajki magicznej, op. cit., s. 51.

[33] Ibidem, s. 61.

[34] Ibidem, s. 59.

[35] Ibidem, s. 313-315.

[36] „Panowało przekonanie, że młodzieniec podczas obrzędu umiera, by później zmartwychwstać już jako nowy człowiek. Była to tak zwana śmierć czasowa”.
Ibidem, s. 53.

[37] Propp dokładnie opisuje symboliczne znaczenie pojenia i karmienia i ich związku ze światem podziemnym. Ibidem, s. 65-68.

[38] Ibidem, s. 66.

[39] Propp odwołuje się do nektaru i ambrozji, gdy opowiada o starożytnych źródłach wyobrażeń związanych ze spożywaniem pokarmów. Ibidem, s. 68 . 
rani także innych ludzi. Cała jego twarz jest pełna śladów po cięciach, których nie ukryją nakładane na nie kosmetyki Peg. Takie nacięcia i powstające z nich blizny stają się dla poddawanego inicjacji młodzieńca widzialnym symbolem jego wtajemniczenia[40]. Cięcia Edwarda mogą być także rozpatrywane jako elementy inicjacji związanej z seksualnością. W scenie rzeźbienia lodowego anioła Edward przypadkiem robi nacięcie na dłoni Kim. Ta, ubrana w białą sukienkę, symbol niewinności, patrzy na ranę, z której zaczyna wypływać krew. Scenę tę można zrozumieć jako symboliczne nawiązanie do obrzędów seksualnych [41], utraty dziewictwa jako kolejnego stopnia wtajemniczenia młodej osoby na drodze od „niewinności” do „doświadczenia”.

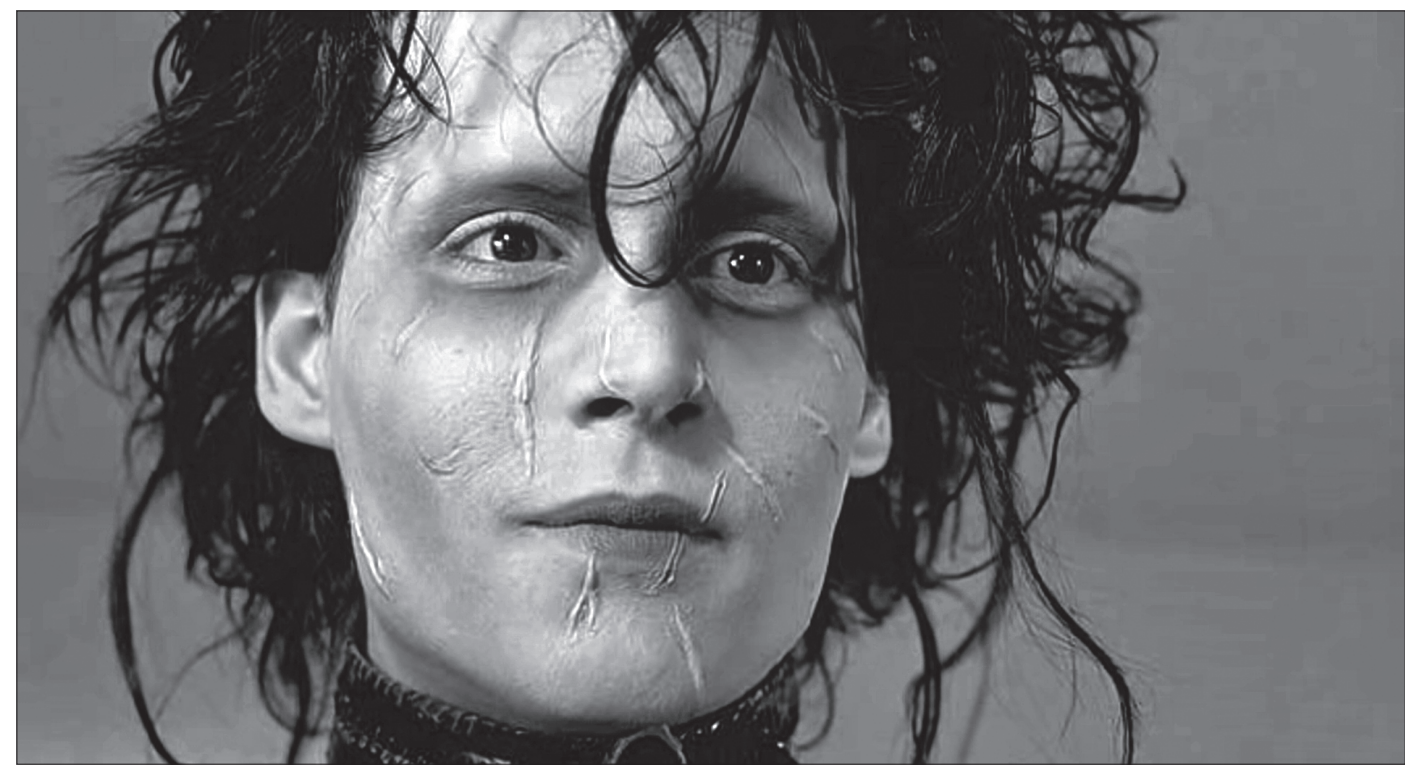

Edward Nożycoręki, reż. Tim Burton (USA, 1990) Twarz Edwarda pokryta jest bliznami, które interpretować można jako symbol skaryfikacji, będącej częścią rytuału inicjacyjnego bohatera.
[40] Ibidem, s. 89 .
W czasie procesu inicjacji Edwarda następuje także szereg zadań, które ma wykonać. Głównie chodzi o używanie nożyc (strzyżenie żywopłotów, psów i ludzkich włosów), przygotowywanie pożywienia (szaszłyki nabijane bezpośrednio na jego nożyce), a także odpowiadanie na pytania (odnoszące się do jego życia w zamku oraz do jego znajomości reguł społecznych). Musi także wykazać się lojalnością w stosunku do Jima i Kim, gdy ci nakłaniają go do współudziału we włamaniu, a potem pozostawiają go samego na pastwę policji. Jego lojalność objawia się w tym, że nie wydaje ich władzom, biorąc tym samym winę na siebie. To właśnie ta ostatnia próba sprawia, że Kim zaczyna odwzajemniać jego uczucie. Odsłania to kolejną funkcję wykonywanych poleceń i przechodzenia inicjacji: dopiero wypełnienie wszystkich zadań i osiągnięcie pełnego wtajemniczenia sprawia, że 
młodzieniec zyskuje „prawo wstępowania w związki małżeńskie”[42]. W tym przypadku oznacza to możliwość zdobycia odwzajemnionej miłości Kim.

$\mathrm{Na}$ koniec swojej inicjacji, tuż przed ucieczką z przedmieść, Edward wchodzi w stan szaleństwa. Demoluje dom, w którym dotychczas mieszkał, niszczy stworzone przez siebie rzeźby z żywopłotów, pędzi w maniakalny sposób przez ulice przedmieść. Jeżeli „[...] moment szaleństwa był chwilą, gdy w inicjowanego wstępował duch, tzn. momentem nabycia odpowiednich zdolności”[43], to właśnie tę sekwencję można uznać za moment, który zdeterminował wynik finałowego pojedynku. Edward przeszedł przez wszystkie etapy inicjacji, znalazł w sobie siłę i motywację do tego, by rozprawić się ze swoim wrogiem. Poszedł do „świata podziemnego” i wracając do siebie, „na górę”, stał się mężczyzną. Na koniec czeka go nagroda: pocałunek i wyznanie miłości kobiety, którą pokochał. Mimo ukończonej inicjacji w społeczeństwie Edward nie wraca już do miasteczka. To, co najważniejsze, już mu się udało: zdobył wiedzę i doświadczenie. Teraz może żyć w swojej samotności, tworząc piękne rzeźby $z$ dala od społeczeństwa, które nie jest go warte.

Zakończenie może się wydawać nietypowe. Brak jest tu oczekiwanego przez widzów happy endu. Wszystko zdaje się bajkowe, ale jakby nie do końca. Tim Burton w wielu momentach łamie schematy baśni. Nie daje widzowi zakończenia, na które on liczy i które wydaje się obowiązkowe z powodu przynależności gatunkowej. Używa schematów inicjacji, ale przekształca je $\mathrm{w}$ taki sposób, aby były zgodne $\mathrm{z}$ jego intuicyjnym rozumieniem świata. Na głównego bohatera baśni wybiera potwora, choć klasycznie potworem powinien być antagonista. Zamiast wypędzać protagonistę do dalekich krajów, Burton wrzuca go w samo serce amerykańskich przedmieść. Widz może zaczać sobie zadawać pytania: co jest prawdziwe, a co jest fantazją? Kto tu jest prawdziwym potworem? Jakich norm należy przestrzegać? Reżyser w jednym z wywiadów twierdzi, że chciał opowiedzieć baśń w klasycznym tego słowa znaczeniu, ale zarazem sprawdzić, a może nawet zakwestionować jej prawdy[44].

Burton sam wychował się na typowych przedmieściach i często podkreśla, że tworząc postać Edwarda, bazował na własnych wspomnieniach. Nigdy nie miał w sobie łatwości nawiązywania kontaktu z drugim człowiekiem i właśnie tę niemożność miały symbolizować nożyce zamiast rąk u Edwarda. „To niezdolność komunikowania się, niemożność dotyku, skłócenie z samym sobą" [45], twierdzi wprost. Realizacja tego filmu była dla niego terapią, sposobem przepracowania problemu, z którym nie mógł sobie poradzić. Bettelheim w swojej pracy[46] opisuje,

[42] W. Propp, Historyczne korzenie bajki magicznej, op. cit., s. 53.

[43] Ibidem, s. 91.

[44] T. Burton, Tim Burton and Vincent Price, rozmowę przeprowadził Graham Fuller, w: Tim Burton.

A Child's Garden of Nightmares, red. P.A. Woods,

London 2007, s. 59.
[45] Ibidem, s. 59.

[46] B. Bettelheim, Cudowne i pożyteczne. O znaczeniach $i$ wartościach baśni, t. 1, przeł. D. Danek, Warszawa 1985. 
jak wielkie psychologiczne i terapeutyczne znaczenie ma opowiadanie bajek magicznych. Twierdzi, że „o wewnętrznych problemach istoty ludzkiej i właściwych sposobach radzenia sobie z trudnym położeniem w każdym społeczeństwie baśnie mówią znacznie więcej niż jakikolwiek inny rodzaj opowieści dla dzieci" [47]. Ma to duże znaczenie, gdy zada się pytanie o taki, a nie inny wybór gatunku przez Burtona. Pozwala także stwierdzić, czemu baśń opowiadająca o inicjacji ma tak duże znaczenie. Bettelheim pisze o tym, że jest w nas głęboka potrzeba identyfikacji $\mathrm{z}$ bohaterem opowiadanej nam historii. Identyfikacja ta jest potrzebna, aby zrozumieć, że „ludzie bardzo różnią się między sobą i że trzeba wybierać, kim się chce być" [48]. Czytając refleksje Bettelheima i słowa Burtona z wywiadów poświęconych Edwardowi Nożycorękiemu, widzimy, jak wielkim i wartościowym narzędziem staje się baśń. Pozwala ona na przepracowanie noszonych w sobie problemów oraz zrozumienie działania świata przez towarzyszenie bohaterowi w jego inicjacji[49].

Świat być może nie jest taki jak baśnie, ale baśnie na pewno odzwierciedlają świat. W mojej pracy starałam się zanalizować użycie struktury baśniowej w filmie Edward Nożycoręki, aby zrozumieć sposób i cel jej użycia. Okazuje się, że bajka magiczna, mimo zakorzenienia w kulturze oralnej i tendencji do zwięzłości, jest doskonałym narzędziem do tworzenia dzieła filmowego. Mimo skomplikowanej budowy filmu i jego dłuższej formy baśniowość w tym dziele audiowizualnym nie traci na prawdziwości i głębokim oddziaływaniu na widza. Burton bierze w swoje ręce każdemu dobrze znaną formułę i używa jej w nieco inny sposób, zyskując dzięki temu zarazem wgląd we własne wnętrze, jak i spojrzenie na uniwersalne prawdy o świecie i społeczeństwie. Widz podążający za Edwardem przeżywa inicjację wraz z nim, zyskując nową, inną perspektywę na świat, w którym żyjemy. Nie wiadomo, czy baśń jest tylko przykrywką dla smutnej rzeczywistości, czy może to codzienne życie skrywa w sobie magiczność. Jak to w baśni, zobaczyć można wyraźny podział na dobro i zło, zrozumieć lekcje wyciągnięte z ciężkich prób i czegoś się nauczyć. Edward koniec końców ucieka od pełnego uprzedzeń i nietolerancyjnego społeczeństwa, skrywa się na swojej górze i trwa w samotności. Po tym, czego nauczyła widza ta baśń, może on zadać sobie pytanie: „A może to właśnie jest happy end?”.

Za pomoc merytoryczna udzielona mi podczas przygotowywania artykutu serdecznie dziękuję Pani Doktor Magdalenie Bednarek z Uniwersytetu im. Adama Mickiewicza w Poznaniu.

[47] Ibidem, str. 42.

[48] Ibidem, str. 49.

[49] Edward Nożycoręki nie jest jedynym dziełem Tima Burtona, które po dogłębnej analizie zdradza istnienie struktur, stylistyki czy cech narracji charakterystycznych dla baśni. Często powracającym wątkiem jest także rytuał inicjacyjny, którego przebieg można zaobserwować u wielu filmowych bohaterów tego reżysera. Takie dzieła, jak Jeździec bez głowy (1999), Duża Ryba (2003), Charlie i fabryka czekolady (2005) czy Alicja w Krainie Czarów (2010), to tylko kilka przykładów filmów, które można poddać podobnemu zabiegowi analizy strukturalnej i stylistycznej, aby odnaleźć w nich wciąż powracające odwołania do baśniowości i rytuałów wtajemniczenia. 